Journal of Urban and Regional Analysis, vol. XII, 2, 2020 , p. 233 - 248

https://doi.org/10.37043/JURA.2020.12.2.7

\title{
MITIGATING FLASH FLOODS WITH THE USE OF NEW TECHNOLOGIES: A MULTI-CRITERIA DECISION ANALYSIS TO MAP FLOOD SUSCEPTIBILITY FOR ZAKYNTHOS ISLAND, GREECE
}

\author{
Stavros STAVROPOULOS ${ }^{1}$, George N. ZAIMES ${ }^{1}$, Evangelos FILIPPIDIS ${ }^{1}$, \\ Daniel C. DIACONU ${ }^{2}$, Dimitrios EMMANOULOUDIS \\ ${ }^{1}$ International Hellenic University, Drama, Greece, ${ }^{2}$ University of Bucharest, \\ Bucharest, Romania
}

\begin{abstract}
Floods can be extremely harmful for the welfare of societies regardless if they are natural or caused by humans. The Mediterranean region has experienced an increase in flash floods frequency and severity. The suddenness and episodic nature of these type of floods makes it more difficult to predict them compared to river floods. In this study, a map was developed in regard to the flood susceptibility of Zakynthos Island with the use a multi-criteria decision analysis. This analysis utilized six factors: a) flow accumulation, b) land use, c) slope, d) rainfall intensity, e) geology and f) elevation. Each factor had a different weight based on their importance in regard to flash floods. The analysis was run in GIS. To validate the developed susceptibility map, the locations of the recorded past floods on the island were utilized. The end product was a validated flood susceptibility map. This map can help the Civil Protection Authority of Zakynthos Island to mitigate communities' susceptibility to flash floods.
\end{abstract}

Key Words: flood susceptibility map, MCDA, GIS, Mediterranean islands.

\section{Introduction}

When large amounts of water exceed the natural boundaries of water bodies and occupy areas that are typically dry, floods occur. Floods are natural hydro-meteorological disasters (Cavallo and Noy 2011). They typically result from extreme meteorological events, such as heavy rainfalls or sudden snowmelts, but they can also be caused by earthquakes, landslides, tsunami or dam failures. Anthropogenic activities have accelerated flash floods frequency and magnitude. Such activities include: a) changes in land-uses (primarily urbanization and agriculture), b) exponential increase in population, c) river regulation of most rivers (dams, channelization) and d) climate changes (Jonkman 2005, Trenberth 2008, Zaimes and Emmanouloudis 2012). When floods are compared to other disasters, they are the costliest, deadliest and most frequent (Gaume et al. 2016). Human life, economic, ecosystem, historical and cultural losses, and associated diseases are some of the direct consequences. The loss of economic and agricultural production and a decrease in the socio-economic welfare are some of the indirect consequences (Jonkman 2005). Flooding consequences are also categorized based on the temporal scale (Cavallo and Noy 2011). Those occurring during the flood event are immediate consequences and include damages to infrastructure, buildings, equipment, roads, bridges, reservoirs and agricultural land. When transportation and services stop being produced or provided, for up to five years after the flood event, they are considered as intermediate consequences. Finally, the changes in the macroeconomic variables, the migration of the population and the devaluation of properties are the long-term consequences. These numerous and wide-ranging consequences have led to global efforts to mitigate flood impacts before, during and after they occur. 
The types of a flood event depend on the location they occur in, the flood water speed and amount, and/or their causes (Heathcote 2009, Zevenbergen et al. 2010, Simonović 2012, Chilikova-Lubomirova and Zaimes 2018, Şen 2018). The main flood categories are: a) river (or fluvial), b) coastal, c) urban, d) flash, e) pluvial, and f) dam and dyke failure. Flash floods are the focal point of this study that are typically caused by very high intensity rainfalls or sudden massive snowmelts (Gaume et al. 2009, Marchi et al. 2010). Their main characteristic is that the water flowing in its channel and/or outside has a very high velocity. This is caused by the steep slopes of their watersheds that lead to high concentration times of the rainfall water that rapidly reaches their channels. Small areas are typically covered with water from flash floods. Still they are very dangerous because the depth and the travelling velocity of the water can be very high and the waters have a large transport capacity that can carry rocks, trees and cars. Finally, most flash floods stop as fast as they start, making them very difficult to predict. Overall, they have not been studied or recorded as extensively as needed in order to completely comprehend them, especially when compared to other types of floods (Lumbroso and Gaume 2012). This is surprising because flash floods in Europe are a major natural disaster (Marchi et al. 2010). The reasons for the limited comprehension of flash floods are: a) they occur in watersheds that do have formal and regular measurements of the discharge or the magnitude of the event; b) flash floods data are recorded in the technical reports of the local authorities, companies and research units, and they typically remain unpublished, so it is difficult to access them, and they are written in the national languages (Gaume et al. 2009).

The complex climate, topography and geomorphology of the Mediterranean Basin leads to many diverse environments, typically prone to flash flooding (Camarasa Belmonte and Segura Beltrán 2001). The Euro-Mediterranean region has more extreme floods than the European continental regions, especially flash floods (Ferraris et al. 2002). The frequent appearance of flash floods is due to the rough mountainous landscape that in many cases is near the coastline (Llasat et al. 2010, Ducrocq et al. 2014). The slopes of the Mediterranean mountains are steep and the altitudinal difference from the mountain top to the coastline is quite large despite the small horizontal distance. Secondly, intense precipitation events are very common in the region (Tarolli et al. 2012, Gaume et al. 2016). Therefore, the watershed hydrologic timescale in the Mediterranean can be only of a few hours (rainfall concentration time). The climate, the topography and geology have also led to its fluvial systems being primarily composed of ephemeral and intermittent streams (Camarasa Belmonte and Segura Beltrán 2001, Emmanouloudis et al. 2011). These types of streams are called 'wadis' in the Eastern and Southern Mediterranean and 'torrents' in the Northern Mediterranean (Emmanouloudis et al. 2011). Flash floods in 'torrents' and 'wadis' are the most extreme in autumn (Ducrocq et al. 2014). In addition, urban settlements have and continue to rapidly expand along the Mediterranean coastlines leading to a greater number of people exposed to flash flooding (Llasat et al. 2016). Finally, flash floods in the region are also the consequence of the frequent wildfires that are a natural disturbance of many Mediterranean ecosystems (Ranis et al. 2015). Burned watersheds are bare of vegetation, thus the surface runoff is high and the hydrologic regime timescale is very quick (García-Comendador et al. 2017).

The climate change potential impact on the hydrology should also be considered. Temperatures and evapotranspiration increases, more intense rainfalls, and rainfall amount declines by $50 \%$ in the summer have been forecasted for the Mediterranean (Terrado et al. 2014). These changes will enhance drought frequency and length and they lead to a quicker hydrological cycle that should reduce even more the water availability in this water-scarce region (Rault et al. 2019). The natural flow regimes of the water bodies are expected to change (Pedro-Monzonís et al. 2016), with perennial streams becoming intermittent and intermittent streams becoming ephemeral. Overall, the flash flood frequency and magnitude are expected to increase. Drought increases will increase the frequency of wildfires and they lead to larger burnt areas thus indirectly increasing the flash floods' potential (Mitsopoulos et al. 2017, Duane et al. 2019). 
In Greece, numerous flash floods are recorded every year (Diakakis and Deligiannakis 2017). This is associated with the intense rainfall events that occur and the rugged, steep mountainous topography of Greece that ends in lowlands along the seacoast, where most people live (Emmanouloudis et al. 2011). The unorganized urban development in Greece, which for many times has led to settlements developed in former torrent channels or floodplains, has also increased the susceptibility to flash flooding impacts. Finally, the areas surrounding the urban centers have frequent wildfires that further exponentially enhance the potential of floods in the cities. In many cases, this fact leads to losses of human lives. A total of 151 deaths were recorded in Greece from 1970 till 2010, caused by 53 flood events (Diakakis and Deligiannakis 2017). Most fatalities, specifically 39, occurred in 1977 due to a major flood in Athens (Diakakis 2014). A similar flood event occurred in Mandra, a town that lies outside of Athens, on November $15^{\text {th }} 2017$, that caused the loss of 24 lives. The event was caused by an extreme rainfall storm, that had $300 \mathrm{~mm}$ of water fall within a $13 \mathrm{~h}$ period (Diakakis et al. 2019). This flash flood had the most deaths in Greece, in the last 40 years. Overall, the rapid population congregation in urban centers, the uncontrolled and unorganized urban development, will lead to more flash flood events, indicating clearly that standardized measures that are science-based need to be taken to mitigate this danger.

This study utilized new technologies and methodologies to develop flood susceptibility maps that identify the areas with the highest susceptibility for the island of Zakynthos in Greece. Few studies have focused on floods on the Greek islands despite a plethora of flood events recorded on Greek islands. These events are typically the result of their rugged topography and the frequent intense rainfalls. In addition, most infrastructure and settlements are along the coastlines, increasing the potential negative impacts of flash floods. Finally, the Flood Directive $2007 / 60 / E C$, that was established to assess and manage flood risks, requires all member states to: a) assess the water courses and coastlines that are at risk from flooding; b) map the flood extent and the assets and humans that are at risk in these areas; and c) implement coordinated measures to reduce these flood risks (European Council 2007). This study addresses the Flood Directive by focusing on a specific flood prone island.

\section{Methodology}

\section{Study area}

The topographic and climatic conditions of the Greek peninsula along with the population congregation in urban centers will enhance the susceptibility and impacts from the frequent flash flood events. Greece has approximately 6000 islands although most are not populated. Islands differ to the inland areas because of their unique hydrometeorological characteristics. This makes them special case studies in regard to flooding events, especially in the Mediterranean. The Greek populated islands have a high hypsometric variability within a relatively small area, with torrents primarily flowing on them (Emmanouloudis et al. 2011). The end points of the torrents are along the seacoast where most development is concentrated, thus enhancing flood vulnerability (Kourgialas and Karatzas 2016, Koutalakis et al. 2017a, Vozinaki et al. 2018, Fortesa et al. 2019).

Zakynthos Island was the focus of this study (Fig. 1). Zakynthos is located in western Greece, in the lonian island cluster. It is one of the larger islands of the lonian cluster. Its total area is $406 \mathrm{~km}^{2}$, while the length of coastline is $123 \mathrm{~km}$, and it is occupied by 41,000 people. It is approximately triangular in shape, with Skinari Cape in the north, and Marathia Cape (on the southwest) and Gerakas Cape (on the southeast) to the south. Between the two southern capes is Laganas Bay, a National Marine Park since 1999. The reason for this designation is because the endangered Caretta-Caretta sea turtle utilizes the island as a nesting ground. This is another reason for focusing on the specific island. The Brachion Peak is the highest point of 
Stavros STAVROPOULOS, George N. ZAIMES, Evangelos FILIPPIDIS, Daniel C. DIACONU, Dimitrios EMMANOULOUDIS

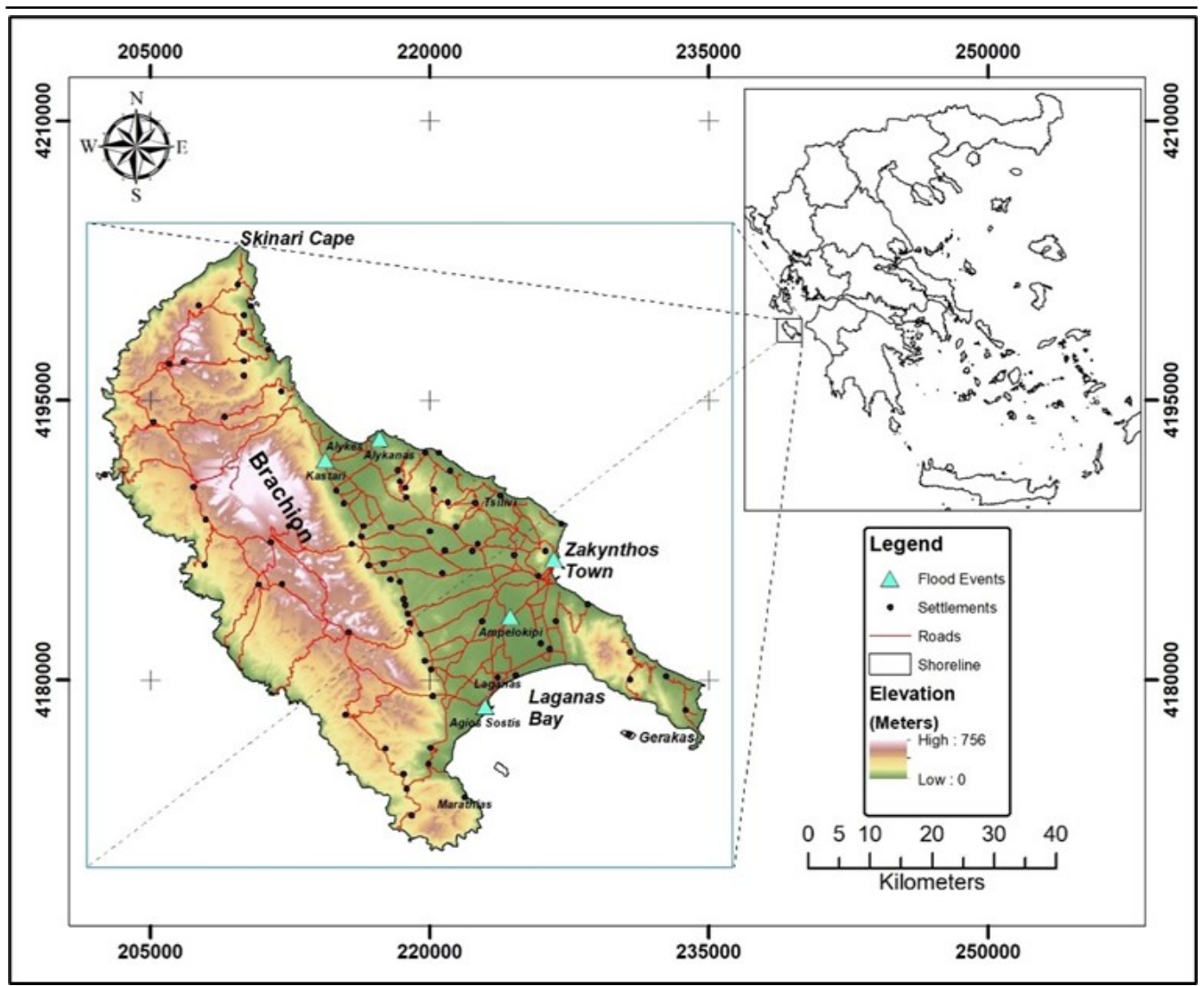

Fig. 1 - Zakynthos Island that is located in the lonian Sea in western Greece was the study area

the island with an elevation of 756 meters. Overall, $55.15 \%$ of the island is semi-mountainous, primarily the western part of the island and the two southern capes (Marathia and Gerakas).

The eastern part has most of the lowlands. In regard to the geology, the western parts are mainly of limestone. The middle of the island has primarily clastic deposits and marly limestones. Finally, the western parts have evaporites that in many instances are overlaid by clastic deposits and marly limestones. Along the seacoast and the lowland areas, you can also find, in small areas, scree, coastal and recent marsh deposits and alluvial and eluvial formations. Zakynthos has a mild Mediterranean climate, and it rarely experiences extreme temperatures. Temperatures below $1-2^{\circ} \mathrm{C}$ have scarcely been recorded, while humidity can reach high levels, as high as $80 \%$, and the average annual precipitation is $940 \mathrm{~mm}$. This results in the island having a rich and dense vegetation. From a hydrological approach, no major rivers flow through the island. Still, the many rainfall events and the high annual amount of rainfall lead to flows through the island torrents that frequently have flash floods. This is the second reason for selecting Zakynthos Island. The island has four main torrents that are Lagana, Zakynthos, Tsilivi and Alykes. All these have an ephemeral flow and they start in mountainous areas, continue in the lowlands and end in the sea. The torrents also run through the settlements of Zakynthos Island (typically in the lowlands) were the greatest susceptibility to floods exists. Housing can be found on both sites of the torrents and some rudimentary flood 
Mitigating Flash Floods with the Use of New Technologies:

a Multi-Criteria Decision Analysis to Map Flood Susceptibility for Zakynthos Island, Greece

prevention infrastructure has been developed (e.g. levees or cement walls or gabions on the banks).

Finally, climate change implication should also be considered. Specific studies for the island have not been conducted. The projections for the Mediterranean region forecast an intensification of the hydrological cycle. Specifically, the temperature is expected to increase, the rainfall will concentrate in shorter periods of time, the precipitation will decrease up to $50 \%$ in the summer, and the drought frequency and strength will increase (Rault et al. 2019). These conditions should lead to a more surface runoff and it is the reason why the frequency of large floods in the region has been forecasted (Calbó 2010).

\section{A Multi-Criteria Decision Analysis within a Geographical Information System to assess flash floods}

Flash floods have an episodic nature. They developed very fast but also they end very sudden. Innovative and modern technologies can help develop state of the art tools for the sustainable management of water resources. This is a major need in the Mediterranean region that is water -scarce and it experiences flash floods quite often (Kourgialas et al. 2015, Maugeri et al. 2015, Diaconu et al. 2019, Koutalakis et al. 2019). Using modern technologies can mitigate torrent damages during flash floods while enabling their utilization to benefit the neighboring communities (Koutalakis et al. 2017a, Koutalakis et al. 2017b, Tufekcioglu et al. 2017).

Combining a Geographic Information System (GIS) with an 'expert system' can be such an innovative tool, particularly for ecosystem and environmental assessments (Gounaridis and Zaimes 2012, Zaimes et al. 2012). GIS provides spatial data analysis and capabilities for analytical modeling (Malczewski 2006). An expert system tries to emulate a human expert in order to transfer knowledge and expertise and to produce recommendations by utilizing reasoning methodologies in a computer-based system (Malczewski 2006, Zaimes et al. 2016). Such a system, that is frequently used because of its flexibility and innovation, is the MultiCriteria Decision Analysis (MCDA). A MCDA can structure decision problems by utilizing science-based approaches and schemes to form, assess and prioritize alternative decisions (Malczewski 2006). The combination of GIS and MCDA can support effectively and efficiently the spatial decision-making process. It can be an optimal tool for land managers to assess flash flood risk because it can provide support but it also helps to quantify the relationships between floods and their influencing factors.

In the recent decades, a major increase in the use of MCDA coupled with GIS has been observed. This is because: firstly, the scientific progress and the use of GIS have increased exponentially; secondly, their acceptance as decision analysis and support methods has been worldwide spread; and, thirdly, the MCDA software with its support modules, that are low-cost and easy to use, is easily coupled with the GIS software and readily available (Malczewski 2006, Goodchild 2010, Zaimes et al. 2016).

MCDA mines knowledge that is translated into a computer language, typically by assigning weights for the most important factors of the studied phenomenon (e.g. flash floods) (Malczewski 1999, Rahman and Saha 2008). The weight (value) for each factor depends on its importance based on the experts' opinions. The most difficult and critical step of this widely used method is the problem structuring. The reason is that different weights and rankings can be produced that depend on the experts' opinions (Malczewski 2006). In this study, the MCDA method was employed within a GIS environment. In addition, the Analytic Hierarchy Process (AHP) and the Weighted Linear Combination (WLC) were used.

The criteria selected for the MCDA were based on the reviewed literature, the availability of 
data and the authors' expertise in regard to flash floods (Li et al. 2019, Toosi et al. 2019). Six criteria were selected that considered topographic, environmental, climatic and anthropogenic parameters (Fig. 2). Each criterion brief description follows: 1) Flow Accumulation - it shows how much water will be accumulated in different locations. Firstly, the Digital Elevation Model (DEM) was develop in order to delineate the Zakynthos watersheds. The fill-sinks and flowdirection algorithms with the ArcHydro's flow-accumulation tool were used to identify the water concentration in each location; 2) Slope. The surface runoff is highly dependent on the watershed topography. Slope's length, steepness and shape are the main parameters that were considered. The DEM was utilized to determine the slope parameters; 3 ) Land Use - it can increase or decrease the soil infiltration that impacts the surface runoff rate and the watershed precipitation concentration time. Smaller watershed concentration times have a higher flash flood susceptibility. The vector data from the CORINE Land Cover of 2018 were utilized. The land uses were: a) industrial and urban areas, b) shrublands and rangelands, c) cultivated areas, d) other agricultural areas, and e) small forested areas; 4) Rainfall intensity. The nearest meteorological stations provided the necessary data. The MFI index was used to estimate the intensity. It was estimated with the following equation (Morgan 2005):

$$
\mathrm{MFI}=\Sigma \mathrm{p}^{2} / \mathrm{P}(\text { equation } 1)
$$

where MFI is the rainfall intensity index, $p$ is the daily monthly rainfall and $P$ is the mean annual rainfall; 5) Geology. Soil infiltration heavily depends on the geologic substrate. High infiltration rates reduce the surface runoff and consequently the flash flooding. The geologic formations of Zakynthos island were separated based on their infiltration capacities: a) impermeable, b) low infiltration, c) medium infiltration, d) high infiltration, and e) very high infiltration; 6) Elevation - it had six categories. Lower elevation areas were considered of a higher susceptibility because they have urban settlements which indicate that flash floods can have more significant impacts. In contrast, higher elevation areas are substantially less populated on the island, which indicates a lower susceptibility.

Four of the six selected factors were quantitative. Specifically, a) flow accumulation, b) slope, c) rainfall and d) elevation. The other two factors, geology and land use, were qualitative and

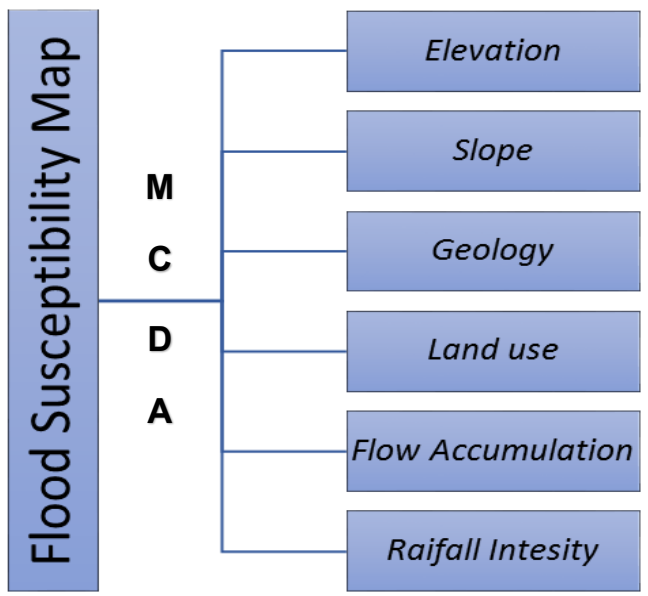

Fig. 2 - Six criteria were used for the Multi-Criteria Decision Analysis (MCDA) to develop the Zakynthos Island Flood Susceptibility Map 
they were modified in order to be able to receive numerical values. All the data used in the MCDA were raster-based. The pixel size was $25 \times 25$ meters. The calibrated values ranged from 1 (very low susceptibility) to 5 (very high susceptibility) depending on the class/category of their original values. This was necessary so that all selected criteria had the same scale. Finally, each criterion received a percentage that was based on their importance according to the experts' opinion on the increasing surface runoff.

For the Final Flash Flood Susceptibility Map, all six selected factors were combined by utilizing the Weighted Linear Combination (WLC) method. This method was implemented in GIS. In this method, each calibrated factor (Xi) is multiplied by its respective weight percentage (Wi). The sum of these gives us the final flood susceptibility map of the study area. This model was developed by using the map algebra in GIS. The equation of the model was:

$$
\mathrm{Ri}=\sum_{\mathrm{i}=0}^{\mathrm{n}} \text { Wi Xi }
$$

where $R$ is defined as the value of risk for pixel $i, n$ the number of criteria used, $W$ is the weight of a criterion $i$ and $X$ is the rank of criterion $i$ according to the range of the criterion values. Each pixel risk value is estimated by considering all criteria, and the criteria values are the input data needed to develop the study area final map.

Finally, validating the results is essential when using a GIS-based MCDA in order to assess its usefulness. Historical recorded data on flash floods locations that were provided by the civil protection authorities were used to validate the identified GIS MCDA high flash flood susceptibility areas of the island.

\section{Results and Discussion}

The classification and calibrating values for each selected factor can be seen in Table 1. Based on these values, six flood susceptibility maps were developed, one for each factor (Fig. 3).

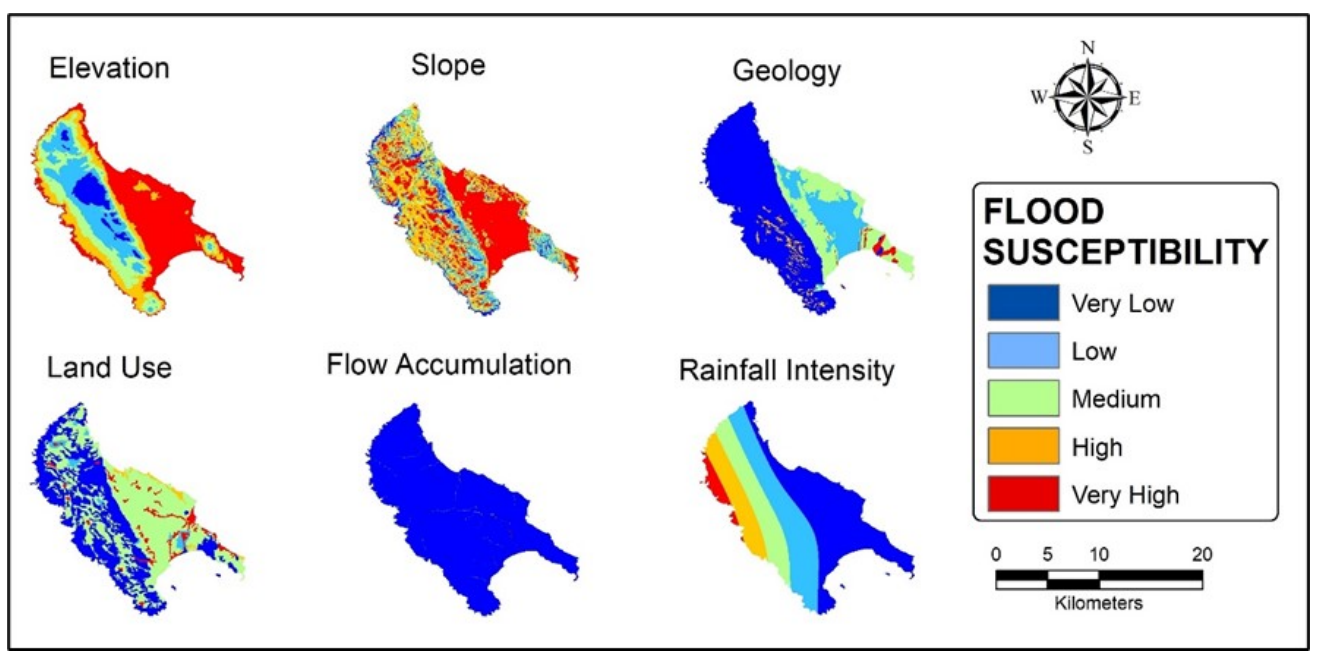

Fig. 3 - A flood susceptibility map was developed for each selected factor 
Stavros STAVROPOULOS, George N. ZAIMES, Evangelos FILIPPIDIS, Daniel C. DIACONU, Dimitrios EMMANOULOUDIS

Table 1

The six criteria weights and rates that were included in the Multi-Criteria Decision Analysis for the flash floods of Zakynthos Island

\begin{tabular}{|c|c|c|c|c|c|c|c|c|}
\hline & Criteria & Classes & $\begin{array}{c}\text { Flash } \\
\text { Flood Risk }\end{array}$ & $\begin{array}{l}\text { Weight } \\
\text { of } \\
\text { Factor }\end{array}$ & Rate & $\begin{array}{c}\text { Corrected } \\
\text { Weight }\end{array}$ & $\begin{array}{c}\text { Total } \\
\text { Weight }\end{array}$ & $\begin{array}{c}\text { Final } \\
\text { Rate } \\
\%\end{array}$ \\
\hline \multirow[t]{5}{*}{1} & \multirow{5}{*}{$\begin{array}{l}\text { Flow } \\
\text { accumu- } \\
\text { lation } \\
\text { (pixels) }\end{array}$} & $\begin{array}{l}81778- \\
110923\end{array}$ & Very High (5) & 10 & \multirow[t]{5}{*}{1.5} & 15 & \multirow[t]{5}{*}{39} & \multirow[t]{5}{*}{9.67} \\
\hline & & $\begin{array}{l}51737- \\
81778 \\
\end{array}$ & High (4) & 8 & & 12 & & \\
\hline & & $\begin{array}{l}26100- \\
51737\end{array}$ & Medium (3) & 5 & & 7.5 & & \\
\hline & & $6525-26100$ & Low (2) & 2 & & 3.0 & & \\
\hline & & $0-6525$ & Very Low (1) & 1 & & 1.5 & & \\
\hline \multirow[t]{5}{*}{2} & \multirow{5}{*}{$\begin{array}{l}\text { Slope } \\
\text { (de- } \\
\text { grees) }\end{array}$} & $0-5$ & Very High (5) & 10 & \multirow[t]{5}{*}{2.0} & 20 & \multirow[t]{5}{*}{52} & \multirow[t]{5}{*}{12.90} \\
\hline & & $5-13$ & High (4) & 8 & & 16 & & \\
\hline & & $13-22$ & Medium (3) & 5 & & 11 & & \\
\hline & & $22-35$ & Low (2) & 2 & & 4 & & \\
\hline & & $35-72$ & Very Low (1) & 1 & & 2 & & \\
\hline \multirow[t]{5}{*}{3} & \multirow[t]{5}{*}{$\begin{array}{l}\text { Land- } \\
\text { use }\end{array}$} & $\begin{array}{l}\text { Urban and } \\
\text { industrial } \\
\text { areas }\end{array}$ & Very High (5) & 10 & \multirow[t]{5}{*}{3.0} & 30 & \multirow[t]{5}{*}{78} & \multirow[t]{5}{*}{19.36} \\
\hline & & $\begin{array}{l}\text { Rangelands } \\
\text { and } \\
\text { shrublands }\end{array}$ & High (4) & 8 & & 24 & & \\
\hline & & $\begin{array}{l}\text { Cultivated } \\
\text { areas }\end{array}$ & Medium (3) & 5 & & 15 & & \\
\hline & & $\begin{array}{l}\text { Other } \\
\text { agricultural } \\
\text { areas }\end{array}$ & Low (2) & 2 & & 6 & & \\
\hline & & $\begin{array}{l}\text { Small for- } \\
\text { ested areas }\end{array}$ & Very Low (1) & 1 & & 3 & & \\
\hline \multirow[t]{5}{*}{4} & \multirow{5}{*}{$\begin{array}{l}\text { Rainfall } \\
\text { Intensity } \\
\text { (Units } \\
\text { MFI) }\end{array}$} & $849-970$ & Very High (5) & 10 & \multirow[t]{5}{*}{1.5} & 15 & \multirow[t]{5}{*}{39} & \multirow[t]{5}{*}{9.67} \\
\hline & & $727-849$ & High (4) & 8 & & 12 & & \\
\hline & & 689-727 & Medium (3) & 5 & & 7.5 & & \\
\hline & & $656-689$ & Low (2) & 2 & & 3 & & \\
\hline & & $638-656$ & Very Low (1) & 1 & & 1.5 & & \\
\hline \multirow[t]{5}{*}{5} & \multirow[t]{5}{*}{ Geology } & $\begin{array}{l}\text { Impermea- } \\
\text { ble }\end{array}$ & Very High (5) & 10 & \multirow[t]{5}{*}{3.0} & 30 & \multirow[t]{5}{*}{78} & \multirow[t]{5}{*}{19.36} \\
\hline & & $\begin{array}{l}\text { Low } \\
\text { infiltration }\end{array}$ & High (4) & 8 & & 24 & & \\
\hline & & $\begin{array}{l}\text { Medium } \\
\text { infiltration }\end{array}$ & Medium (3) & 5 & & 15 & & \\
\hline & & $\begin{array}{l}\text { High } \\
\text { infiltration }\end{array}$ & Low (2) & 2 & & 6 & & \\
\hline & & Calcareous & Very Low (1) & 1 & & 3 & & \\
\hline \multirow[t]{5}{*}{6} & \multirow{5}{*}{$\begin{array}{l}\text { Eleva- } \\
\text { tion } \\
\text { (meters) }\end{array}$} & $0-104$ & Very High (5) & 10 & \multirow[t]{5}{*}{4.5} & 45 & \multirow[t]{5}{*}{117} & 29.04 \\
\hline & & $104-246$ & High (4) & 8 & & 36 & & \\
\hline & & $246-379$ & Medium (3) & 5 & & 23 & & \\
\hline & & $379-515$ & Low (2) & 2 & & 9 & & \\
\hline & & $515-756$ & Very Low (1) & 1 & & 5 & & \\
\hline $\mathrm{Tc}$ & & & & & & & 403 & 100 \\
\hline
\end{tabular}


These maps show how different factors identified other areas with very high susceptibility. The elevation factor identified the coastal areas around the island and the southwestern region of the island as the most susceptible to severe flooding. The southwestern region of the island was again the most susceptible to flooding based on the slope factor, but the coastal areas were identified with very low susceptibility. The overall geology of the island has a high infiltration and only the southwestern cape has areas with a very high flood susceptibility. The land-uses identified very few areas of very high susceptibility that were primarily the urban areas. In these areas, flood mitigation measures should be implemented, since flash floods in these areas can have major negative impacts (e.g. loss of human lives). The areas most likely to have floods, based on the flow accumulation factor, are the channels of the island's torrents, since most surface waters are collected in them. Finally, the greatest amount of rainfall falls in the eastern region of Zakynthos, indicating the greatest runoff potential. By reviewing the six maps, the complexity of flash floods and the influence of each factor on the flood magnitudes and susceptibility are evident. Incorporating all six factors is necessary to accurately forecast the potential locations of high-susceptibility to flash floods.

The flood susceptibility model of this study utilized map algebra in GIS to incorporate all six factors selected that allowed the development of the final flood susceptibility map for Zakynthos Island (Fig. 4). The areas with the highest susceptibility of flooding are marked in red on the map, and they are primarily located in the eastern lowlands and the urban areas of Zakynthos. In these populated areas, flash floods have the potential to cause serious social and economic damages.

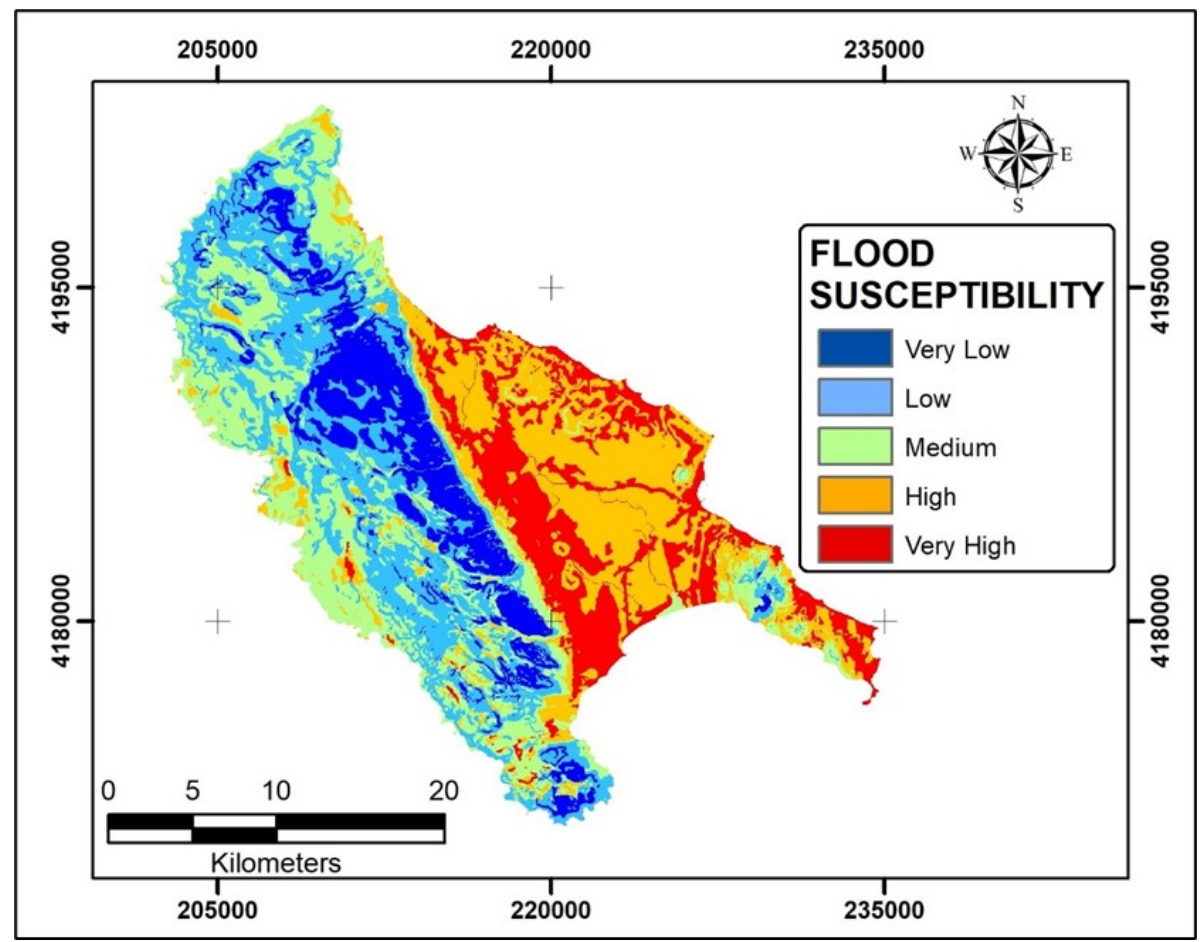

Fig. 4 - The final flood susceptibility map for Zakynthos Island 
To validate the map, the areas in red (e.g. high susceptibility) were compared to the historically recorded floods, data that were provided by the local authorities. Major flood events had previously occurred in Zakynthos: in Katastari in 1992; in Laganas, Ag. Sostis and Alykanas in 2005, and in Zakynthos Town and Ampelokipoi in 2016. The comparison of the recorded flooded areas with the final map produced revealed that all of them produced within the high and very high flood susceptibility areas. This showcases the validity of the applied method and the usefulness of the final map to the local authorities for future flood mitigation and protection.

Floods in the Mediterranean region are a major natural disaster (Diakakis et al. 2018). Every year, the region has many economic losses and, in many cases, losses of lives, because of this disaster. The frequency and magnitude of floods are expected to increase due to climate change and they are forecasted to become more extreme in magnitude in Greece (Giannakopoulos et al. 2011, Roudier et al. 2016). This clearly indicates that there is a need to develop tools to mitigate the future impacts of floods at regional and local scale. This is also a requirement for all EU member states based on the Flood Directive of 2007. Specifically, the member states of the EU need to: a) map the river basin districts of each river; b) register the flood history of the districts and also include information on the flooded areas and the consequences on the society; and c) evaluate the future potentially negative flood consequences on the human society taking into consideration health, the environment, the cultural heritage and the economy (European Council 2007). Once these activities are completed, the most susceptible areas need to be recorded and presented in the form of maps of flood risk potential. The method that was presented here could help the responsible authorities to meet the Flood Directive mandatory requirements.

Emphasis should be given to the populated islands of Greece and in general of the Mediterranean since these can be very crowded due to tourism and in many cases urban planning is very poor and unorganized which could lead to severe problems if flash flood events occur. To better combat this problem, tools that are based on new and modern technologies should be utilized (Kourgialas and Karatzas 2011, Artinyan et al. 2016, Kourgialas and Karatzas 2017). Such an approach is presented in this study that focuses on a Greek island (specifically Zakynthos) and the end result is represented by the easy to read and utilize maps. Such maps should be developed for all the Greek islands that are inhabited. This will allow the Civil Protection, municipalities and urban planners to be more efficient and effective in minimizing the human and economic losses from flooding.

Based on the final map, several urban areas have very high and high susceptibility to flooding. These areas are typically at or close to the mouth of the four torrents of the island. These include the town of Zakynthos and the settlements of Tsivili, Alikananas and Laganas that are all located on the southern and eastern seacoast of the island. Immediate measures need to be taken in these urban areas. Specifically, some of the potential measures could include levees and gabions on the banks while, in the channel, check dams could be constructed or, if possible, the deepening and widening of the channels could be realized. Another solution could be the development of detention and retention ponds that should collect the runoff and increase the concentration time that the runoff requires to reach the channel, thus reducing the flood peaks. Of course, for the selection of the final measures, detailed studies need to be conducted at the local level, taking into consideration the type of infrastructure (e.g. houses, parks etc.), the torrents and the areas most likely to be flooded because of the topography. Finally, the future urban planning should try to avoid building new housing and hotel developments in potential flood zones.

While these measures might prove effective in the short-term, as the towns and villages continue to expand, more sustainable solutions need to be implemented. Specifically, for each of the four torrents of the island, integrated water resources management (IWRM) plans need 
Mitigating Flash Floods with the Use of New Technologies:

a Multi-Criteria Decision Analysis to Map Flood Susceptibility for Zakynthos Island, Greece

to be developed (Le Page et al. 2020). These have been very successful in providing a sustainable water management throughout the world (Hülsmann et al. 2019, Chang et al. 2020). One of the key components is working at the watershed scale and incorporating all hydrologic processes at this scale. In the case of flood management, the goal is to reduce the amount of the runoff water that reaches the stream channel or altering the concentration time of the surface runoff reaching the stream to reduce the flood peaks. The principle is to take mitigation measure before the water reaches the channel. The idea is to implement ecosystembased (Dhyani et al. 2018, Hülsmann et al. 2019) and ecohydrological (Janauer 2016) approaches, and nature-based solutions (Bridgewater 2018, Zaimes et al. 2019a, Brillinger et al. 2020), which are more sustainable and environmentally friendly ways to reduce flooding in the long-term. For example, these could be the establishment and maintenance of the natural riparian vegetation along the torrents (Zaimes et al. 2019b) and the wetlands in the targeted locations of the watershed (Wu et al. 2020).

Overall, the major types of surface water bodies on these islands are the torrents. Torrents, by nature, have a very extreme hydrologic regime that can range from no flow to a flash flood in a matter of hours (Emmanouloudis et al. 2011). This makes them extremely unpredictable and very difficult to manage. It is a necessity to improve our understanding of the processes that govern these systems (Koutalakis et al. 2017a). It will be essential to develop and utilize tools that predict flows for semi-arid intermittent and ephemeral streams (Tzoraki et al. 2013) and especially peak flows from poorly or ungauged torrents (Koutroulis and Tsanis 2010) that run through the urban settings (Papaioannou et al. 2018). Finally, enhancing the awareness of the general public on the impacts of flash floods events, along with mitigation measures, before, during and after these events, should also be a major priority for the Civil Protection Authorities of Greece (Diakakis et al. 2018).

\section{Conclusions}

The areas of Zakynthos Island that have the greatest flood susceptibility were identified by implementing MCDA in a GIS environment. Six factors that influence flash floods were selected and different weights were assigned to them based on the experts' opinions on their importance to this phenomenon. The algebraic sum of the above six factors in GIS categorized the study area into five susceptibility zones, from very low to very high. The results were very satisfactory since the very high susceptibility areas corresponded to the areas that experience flood events in the past.

Improvements can be made to this method. The lack of detailed data on some of the factors was the main source of uncertainty for the results of this study. This uncertainty was related to the geological and land-uses data (too coarse resolution), the lack of high-resolution terrain data (topography), and the few meteorological stations located on the island. Improving the resolution and the spatial accuracy of data would substantially improve the results of this method. Improvements could also be accomplished by including additional factors such as watershed area, watershed stream density, soil type, vegetation cover, population density, road network and the existence of flood mitigation measures.

Overall, the results were very promising. Similar maps, based on this method, should be developed for other islands or regions of Greece that face flash floods. One of the main advantages is the relatively easy implementation of the method. The production of such maps will be very useful to the Civil Protection Authorities of Greece for many reasons. The use of these maps would showcase the areas were flash floods events could occur. This would allow the early evacuation of these areas during flash floods. In addition, the flood mitigation infrastructure and other measures, would be constructed by relying on science-based information in the most needed areas (targeted approach). 
Climate change and the continued expansion of urbanization are expected to increase the flood events' frequency and magnitude. This is particularly true for Greece and the Mediterranean, where fatalities due to flash floods have been recorded in the recent past years. These facts necessitate the utilization of modern and innovative methodologies to mitigate flash floods, particularly into urban settings. Methods such or similar to this study can be an important tool for Greece and the Mediterranean. Civil protection authorities should adapt such methods since they provide a cost-effectively alternative to protect the citizens from this natural disaster. Municipalities should also avoid urban development in areas that have high susceptibility to floods. Finally, more prevention measures need to be implemented in the high susceptibility flash flood areas, at both the local urban scale and the watershed scale, along with enhancing the awareness through various activities with the citizens of these areas.

\section{References}

ARTINYAN E., VINCENDON B., KROUMOVA K., NEDKOV N., TSAREV P., BALABANOVA S., KOSHINCHANOV G. (2016), Flood forecasting and alert system for Arda River basin, Journal of Hydrology 541 (Part A), 457-470.

BRIDGEWATER P. (2018), Whose nature? What solutions? Linking Ecohydrology to Nature-based solutions, Ecohydrology \& Hydrobiology 18 (4), 311-316.

BRILLINGER M., DEHNHARDT A., SCHWARZE R., ALBERT C. (2020), Exploring the uptake of nature-based measures in flood risk management: Evidence from German federal states, Environmental Science \& Policy 110, 14-23.

CALBÓ J. (2010), Possible Climate Change Scenarios with Specific Reference to Mediterranean Regions, in: Sabater S., Barceló D. (eds.), Water Scarcity in the Mediterranean. The Handbook of Environmental Chemistry, vol. 8, Springer, Berlin, pp. 1-13.

CAMARASA BELMONTE A. M., SEGURA BELTRÁN F. (2001), Flood events in Mediterranean ephemeral streams (ramblas) in Valencia region, Spain, CATENA 45 (3), 229249.

CAVALLO E., NOY I. (2011), Natural Disasters and the Economy - A survey, International Review of Environmental and Resource Economics 5 (1), 63-102.

CHANG I.-S., ZHAO M., CHEN Y., GUO X., ZHU Y., WU J., YUAN T. (2020), Evaluation on the integrated water resources management in China's major cities - - Based on City Blueprint $\circledast$ Approach, Journal of Cleaner Production 262, 121410.

CHILIKOVA-LUBOMIROVA M., ZAIMES G. (2018), River Hydraulics during Flood Events: The Balkan Experiences, MATEC Web of Conferences 145, 03002.

DIACONU D. C., BRETCAN P., PEPTENATU D., TANISLAV D., MAILAT E. (2019), The importance of the number of points, transect location and interpolation techniques in the analysis of bathymetric measurements, Journal of Hydrology 570, 774-785.

DIAKAKIS M. (2014), An inventory of flood events in Athens, Greece, during the last 130 years. Seasonality and spatial distribution, Journal of Flood Risk Management 7 (4), 332343.

DIAKAKIS M., DELIGIANNAKIS G. (2017), Flood fatalities in Greece: 1970-2010, Journal of Flood Risk Management 10 (1), 115-123.

DIAKAKIS M., PRISKOS G., SKORDOULIS M. (2018), Public perception of flood risk in flash flood prone areas of Eastern Mediterranean: The case of Attica Region in Greece, International Journal of Disaster Risk Reduction 28, 404-413.

DIAKAKIS M., ANDREADAKIS E., NIKOLOPOULOS E. I., SPYROU N. I., GOGOU M. E., DELIGIANNAKIS G., KATSETSIADOU N. K., ANTONIADIS Z., MELAKI M., GEORGAKOPOULOS A., TSAPROUNI K., KALOGIROS J., LEKKAS E. (2019), An integrated approach of ground and aerial observations in flash flood disaster investigations. The case of the 2017 Mandra flash flood in Greece, International Journal of Disaster Risk Reduction 33, 290-309.

DUANE A., AQUILUÉ N., CANELLES Q., MORÁN-ORDOÑEZ A., DE CÁCERES M., 
BROTONS L. (2019), Adapting prescribed burns to future climate change in Mediterranean landscapes, Science of The Total Environment 677, 68-83.

DUCROCQ V., BRAUD I., DAVOLIO S., FERRETTI R., FLAMANT C., JANSA A., KALTHOFF N., RICHARD E., TAUPIER-LETAGE I., AYRAL P.-A., BELAMARI S., BERNE A., BORGA M., BOUDEVILLAIN B., BOCK O., BOICHARD J.-L., BOUIN M.-N., BOUSQUET O., BOUVIER C., CHIGGIATO J., CIMINI D., CORSMEIER U., COPPOLA L., COCQUEREZ P., DEFER E., DELANOË J., DI GIROLAMO P., DOERENBECHER A., DROBINSKI P., DUFOURNET Y., FOURRIÉ N., GOURLEY J. J., LABATUT L., LAMBERT D., LE COZ J., MARZANO F. S., MOLINIÉ G., MONTANI A., NORD G., NURET M., RAMAGE K., RISON W., ROUSSOT O., SAID F., SCHWARZENBOECK A., TESTOR P., VAN BAELEN J., VINCENDON B., ARAN M., TAMAYO J. (2014), HyMeX-SOP1: The Field Campaign Dedicated to Heavy Precipitation and Flash Flooding in the Northwestern Mediterranean, Bulletin of the American Meteorological Society 95 (7), 1083-1100.

DHYANI S., LAHOTI S., KHARE S., PUJARI P., VERMA P. (2018), Ecosystem based Disaster Risk Reduction approaches (EbDRR) as a prerequisite for inclusive urban transformation of Nagpur City, India, International Journal of Disaster Risk Reduction 32, 95105.

EMMANOULOUDIS D., RODRÍGUEZ J. L. G., ZAIMES G. N., SUÁREZ M. C. G., FILIPPIDIS E. (2011), Euro-Mediterranean torrents: Case studies on tools that can improve their management, in: Richards K. E. (ed.), Mountain Ecosystems: Dynamics, Management and Conservation, Nova Science Publishers, New York, pp. 1-44.

EUROPEAN COUNCIL (2007), EU Directive of the European Parliament and of the European Council on the estimation and management of flood risks (2007/60/EC), Publications Office of the European Union, Luxembourg.

FERRARIS L., RUDARI R., SICCARDI F. (2002), The Uncertainty in the Prediction of Flash Floods in the Northern Mediterranean Environment, Journal of Hydrometeorology 3 (6), 714-727.

FORTESA J., GARCÍA-COMENDADOR J., CALSAMIGLIA A., LÓPEZ-TARAZÓN J. A., LATRON J., ALORDA B., ESTRANY J. (2019), Comparison of stage/discharge rating curves derived from different recording systems: Consequences for streamflow data and water management in a Mediterranean island, The Science of the Total Environment 665, 968-981.

GARCÍA-COMENDADOR J., FORTESA J., CALSAMIGLIA A., CALVO-CASES A., ESTRANY J. (2017), Post-fire hydrological response and suspended sediment transport of a terraced Mediterranean catchment, Earth Surface Processes and Landforms 42 (14), 22542265.

GAUME E., BAIN V., BERNARDARA P., NEWINGER O., BARBUC M., BATEMAN A., BLAŠKOVIČOVÁ L., BLÖSCHL G., BORGA M., DUMITRESCU A., DALIAKOPOULOS I., GARCIA J., IRIMESCU A., KOHNOVA S., KOUTROULIS A., MARCHI L., MATREATA S., MEDINA V., PRECISO E., SEMPERE-TORRES D., STANCALIE G., SZOLGAY J., TSANIS I., VELASCO D., VIGLIONE A. (2009), A compilation of data on European flash floods, Journal of Hydrology 367 (1-2), 70-78.

GAUME E., BORGA M., LLASSAT M. C., MAOUCHE S., LANG M., DIAKAKIS M. (2016), Sub-chapter 1.3.4. Mediterranean extreme floods and flash floods, in: Thiébault S., Moatti J.-P. (eds.), The Mediterranean Region under Climate Change. A Scientific Update: abridged English/French version, IRD Editions, Marseille, pp. 133-144.

GIANNAKOPOULOS C., KOSTOPOULOU E., VAROTSOS K. V., TZIOTZIOU K., PLITHARAS A. (2011), An integrated assessment of climate change impacts for Greece in the near future, Regional Environmental Change 11, 829-843.

GOODCHILD M. F. (2010), Twenty years of progress: GIScience in 2010, Journal of Spatial Information Science 1, 3-20.

GOUNARIDIS D., ZAIMES G. N. (2012), GIS-based multicriteria decision analysis applied for environmental issues; the Greek experience, International Journal of Applied Environmental Sciences 7 (3), 307-321. 
Stavros STAVROPOULOS, George N. ZAIMES, Evangelos FILIPPIDIS, Daniel C. DIACONU, Dimitrios EMMANOULOUDIS

HEATHCOTE I. W. (2009), Integrated watershed management: principles and practice, $2^{\text {nd }}$ edition, John Wiley \& Sons, Hoboken.

HÜLSMANN S., SUŠNIK J., RINKE K., LANGAN S., VAN WIJK D., JANSSEN A. B. G., MOOIJ W. M. (2019), Integrated modelling and management of water resources: the ecosystem perspective on the nexus approach, Current Opinion in Environmental Sustainability 40, 14-20.

JANAUER G. A. (2016), Ecohydrology, floodplain water bodies, European legal provisions and the future, Ecohydrology \& Hydrobiology 16 (1), 58-65.

JONKMAN S. N. (2005), Global Perspectives on Loss of Human Life Caused by Floods, Natural Hazards 34, 151-175.

KOURGIALAS N. N., KARATZAS G. P. (2011), Flood management and a GIS modelling method to assess flood-hazard areas - a case study, Hydrological Sciences Journal 56 (2), 212-225.

KOURGIALAS N. N., DOKOU Z., KARATZAS G. P. (2015), Statistical analysis and ANN modeling for predicting hydrological extremes under climate change scenarios: The example of a small Mediterranean agro-watershed, Journal of Environmental Management 154, 86-101.

KOURGIALAS N. N., KARATZAS G. P. (2016), A flood risk decision making approach for Mediterranean tree crops using GIS; climate change effects and flood-tolerant species, Environmental Science and Policy 63, 132-142.

KOURGIALAS N. N., KARATZAS G. P. (2017), A national scale flood hazard mapping methodology: The case of Greece - Protection and adaptation policy approaches, Science of the Total Environment 601-602, 441-452.

KOUTALAKIS P., VLACHOPOULOU A., EMMANOULOUDIS D., ZAIMES G. $\mathrm{N}$ (2017a), Simulation of torrent discharge using SWAT and evaluation by field survey in Thasos Island, Journal of Engineering Science and Technology Review 10 (3), 7-10.

KOUTALAKIS P., ZAIMES G. N., IOANNOU K., IAKOVOGLOU V. (2017b), Application of the SWAT model on torrents of the Menoikio, Greece, Fresenius Environmental Bulletin 26 (2), 1210-1215.

KOUTALAKIS P., TZORAKI O., ZAIMES G. (2019), UAVs for Hydrologic Scopes: Application of a Low-Cost UAV to Estimate Surface Water Velocity by Using Three Different Image-Based Methods, Drones 3 (1), 14.

KOUTROULIS A. G., TSANIS I. K. (2010), A method for estimating flash flood peak discharge in a poorly gauged basin: Case study for the 13-14 January 1994 flood, Giofiros basin, Crete, Greece, Journal of Hydrology 385 (1-4), 150-164.

LE PAGE M., FAKIR Y., AOUISSI J. (2020), Chapter 7 - Modeling for integrated water resources management in the Mediterranean region, in: Zribi M., Brocca L., Tramblay Y., Molle F. (eds.), Water Resources in the Mediterranean Region, Elsevier, New York, pp. 157-190.

LI W., LIN K., ZHAO T., LAN T., CHEN X., DU H., CHEN H. (2019), Risk assessment and sensitivity analysis of flash floods in ungauged basins using coupled hydrologic and hydrodynamic models, Journal of Hydrology 572, 108-120.

LLASAT M. C., LLASAT-BOTIJA M., PRAT M. A., PORCÚ F., PRICE C., MUGNAI A., LAGOUVARDOS K., KOTRONI V., KATSANOS D., MICHAELIDES S., YAIR Y., SAVVIDOU K., NICOLAIDES K. (2010), High-impact floods and flash floods in Mediterranean countries: The FLASH preliminary database, Advances in Geosciences 23, 47-55.

LLASAT M. C., MARCOS R., TURCO M., GILABERT J., LLASAT-BOTIJA M. (2016), Trends in flash flood events versus convective precipitation in a Mediterranean region: The case of Catalonia, Journal of Hydrology 541 (Part A), 24-37.

LUMBROSO D., GAUME E. (2012), Reducing the uncertainty in indirect estimates of extreme flash flood discharges, Journal of Hydrology 414-415, 16-30. New York.

MALCZEWSKI J. (1999), GIS and Multicriteria Decision Analysis, John Wiley \& Sons, 
Mitigating Flash Floods with the Use of New Technologies:

a Multi-Criteria Decision Analysis to Map Flood Susceptibility for Zakynthos Island, Greece

MALCZEWSKI J. (2006), GIS-based multicriteria decision analysis: a survey of the literature, International Journal of Geographical Information Science 20 (7), 703-726.

MARCHI L., BORGA M., PRECISO E., GAUME E. (2010), Characterization of selected extreme flash floods in Europe and implications for flood risk management, Journal of Hydrology 394 (1-2), 118-133.

MAUGERI M., BRUNETTI M., GARZOGLIO M., SIMOLO C. (2015), High-resolution analysis of 1 day extreme precipitation in Sicily, Natural Hazards and Earth System Sciences 15 (10), 2347-2358.

MITSOPOULOS I., MALLINIS G., ZIBTSEV S., YAVUZ M., SAGLAM B., KUCUK O., BOGOMOLOV V., BORSUK A., ZAIMES G. (2017), An integrated approach for mapping fire suppression difficulty in three different ecosystems of Eastern Europe, Journal of Spatial Science 62 (1), 139-155. Oxford.

MORGAN R. P. C. (2005), Soil Erosion and Conservation, $3^{\text {rd }}$ edition, Wiley-Blackwell,

PAPAIOANNOU G., EFSTRATIADIS A., VASILIADES L., LOUKAS A., PAPALEXIOU S. M., KOUKOUVINOS A., TSOUKALAS I., KOSSIERIS P. (2018), An operational method for Flood Directive implementation in ungauged urban areas, Hydrology 5 (2), 24

PEDRO-MONZONÍS M., DEL LONGO M., SOLERA A., PECORA S., ANDREU J. (2016), Water Accounting in the Po River Basin Applied to Climate Change Scenarios, Procedia Engineering 162, 246-253.

RAHMAN M., SAHA S. K. (2008), Remote sensing, spatial multi criteria evaluation (SMCE) and analytical hierarchy process (AHP) in optimal cropping pattern planning for a flood prone area, Journal of Spatial Science 53 (2), 161-177.

RANIS G. D., IAKOVOGLOU V., ZAIMES G. N. (2015), Ecosystem Post-Wildfire Effects of Thasos Island, International Journal of Environmental and Ecological Engineering 9 (10), $1282-1285$

RAULT P. A. K., KOUNDOURI P., AKINSETE E., LUDWIG R., HUBER-GARCIA V TSANI S., ACUNA V., KALOGIANNI E., LUTTIK J., KOK K., SKOULIKIDIS N., FROEBRICH J. (2019), Down scaling of climate change scenarii to river basin level: A transdisciplinary methodology applied to Evrotas river basin, Greece, Science of The Total Environment 660, 1623-1632.

ROUDIER P., ANDERSSON J. C. M., DONNELLY C., FEYEN L., GREUELL W., LUDWIG F. (2016), Projections of future floods and hydrological droughts in Europe under a $+2^{\circ} \mathrm{C}$ global warming, Climatic Change 135, 341-355. York. ŞEN Z. (2018), Flood Modeling, Prediction and Mitigation, $1^{\text {st }}$ edition, Springer, New

SIMONOVIĆ S. P. (2012), Floods in a Changing Climate: Risk Management, $1^{\text {st }}$ edition, Cambridge University Press, Cambridge.

TAROLLI P., BORGA M., MORIN E., DELRIEU G. (2012), Analysis of flash flood regimes in the North-Western and South-Eastern Mediterranean regions, Natural Hazards and Earth System Sciences 12, 1255-1265.

TERRADO M., ACUÑA V., ENNAANAY D., TALLIS H., SABATER S. (2014), Impact of climate extremes on hydrological ecosystem services in a heavily humanized Mediterranean basin, Ecological Indicators 37 (Part A), 199-209.

TOOSI A. S., CALBIMONTE G. H., NOURI H., ALAGHMAND S. (2019), River basinscale flood hazard assessment using a modified multi-criteria decision analysis approach: A case study, Journal of Hydrology 574, 660-671.

TRENBERTH K. E. (2008), The Impact of Climate Change and Variability on Heavy Precipitation, Floods, and Droughts, in: Anderson M. H. (ed.), Encyclopedia of Hydrological Sciences, J. Wiley and Sons, Chichester.

TZORAKI O., COOPER D., KJELDSEN T., NIKOLAIDIS N. P., GAMVROUDIS C., FROEBRICH J., QUERNER E., GALLART F., KARALEMAS N. (2013), Flood generation and classification of a semi-arid intermittent flow watershed: Evrotas river, International Journal of River Basin Management 11 (1), 77-92. 
Stavros STAVROPOULOS, George N. ZAIMES, Evangelos FILIPPIDIS, Daniel C. DIACONU, Dimitrios EMMANOULOUDIS

TUFEKCIOGLU M., YAVUZ M., ZAIMES G. N., DINC M., KOUTALAKIS P., TUFEKCIOGLU A. (2017), Application of Soil Water Assessment Tool (SWAT) to suppress wildfire at Bayam Forest, Turkey, Journal of Environmental Biology 38 (5), 719-726.

WU Y., ZHANG G., ROUSSEAU A. N., XU Y. J., FOULON É. (2020), On how wetlands can provide flood resilience in a large river basin: A case study in Nenjiang river Basin, China, Journal of Hydrology 587, 125012.

VOZINAKI A.-E. K., TAPOGLOU E., TSANIS I. K. (2018), Hydrometeorological impact of climate change in two Mediterranean basins, International Journal of River Basin Management 16 (2), 245-257.

ZAIMES G. N., EMMANOULOUDIS D. (2012), Sustainable Management of the Freshwater Resources of Greece, Journal of Engineering Science and Technology Review 5 (1), 77-82.

ZAIMES G. N., GOUNARIDIS D., IAKOVOGLOU V., EMMANOULOUDIS D. (2012), Assessing soil erosion risk for Rhodes island, Greece with a GIS-based multi-criteria decision analysis, Proceedings of the IASTED International Conference on Water Resource Management, 317-324.

ZAIMES G. N., TUFEKCIOGLU M., TUFEKCIOGLU A., ZIBTSEV S., COROBOV R., EMMANOULOUDIS D., URATU R., GHULIJANYAN A., BORSUK A., TROMBITSKY I. (2016), Transboundary Collaborations to Enhance Wildfire Suppression in Protected Areas of the Black Sea Region, Journal of Engineering Science and Technology Review 9 (1), 108-114.

ZAIMES G. N., TARDIO G., IAKOVOGLOU V., GIMENEZ M., GARCIA-RODRIGUEZ J. L., SANGALLI P. (2019a), New tools and approaches to promote soil and water bioengineering in the Mediterranean, Science of The Total Environment 693, 133677.

ZAIMES G. N., TUFEKCIOGLU M., SCHULTZ R. C. (2019b), Riparian Land-Use Impacts on Stream Bank and Gully Erosion in Agricultural Watersheds: What We Have Learned, Water 11, 1343.

ZEVENBERGEN C., CASHMAN A., EVELPIDOU N., PASCHE E., GARVIN S., ASHLEY R. (2010), Urban Flood Management, CRC Press, Boca Raton.

Initial submission: 05.10.2019

Revised submission: 23.06.2020

Final acceptance: 27.07.2020

Correspondence: Department of Forestry and Natural Environment, International Hellenic University (IHU), 1st km Drama - Microhoriou, Drama, 66100, Greece.

Email: zaimesg@teiemt.gr 